\title{
Effect of pulegone on the NLPR3 inflammasome during inflammatory activation of THP-1 cells
}

\author{
QINGXIN YANG ${ }^{1,2 *}$, QI LIU ${ }^{*}$, HONGJUN LV${ }^{1}$, FENG WANG $^{1}$, RONG LIU $^{1}$ and NAN ZENG ${ }^{1}$ \\ ${ }^{1}$ Department of Pharmacology, College of Pharmacy, Chengdu University of TCM, Chengdu, Sichuan 611137; \\ ${ }^{2}$ Department of Pharmacology, Sichuan College of Traditional Chinese Medicine, Mianyang, Sichuan 621000, P.R. China
}

Received February 22, 2019; Accepted October 9, 2019

DOI: $10.3892 /$ etm.2019.8327

\begin{abstract}
Pulegone is a key active component of Schizonepeta essential oil and has been determined to have anti-inflammatory properties. However, the underlying molecular mechanisms with regard to the NLR family pyrin domain containing 3 (NLRP3) inflammasome, also known as the NALP3 inflammasome, have remained to be elucidated. NLRP3 represents a potential link between inflammation and immunity and may play possible key role in various pathologies. In the present study, the modulatory effects of pulegone on the NLRP3 inflammasome were investigated. THP-1 cells induced with phorbol myristate acetate were divided into various groups, including the Normal (control), lipopolysaccharide (LPS), $\mathrm{LPS}+\mathrm{ATP} /$ nigericin, LPS + ATP/nigericin + 0.2\% DMSO and pulegone $(0.2,0.1$ and $0.05 \mathrm{mg} / \mathrm{ml})$ groups. ELISA was used to detect the levels of interleukin (IL)-1 $\beta$ and IL-18 in the cell supernatants and the influence of potassium ions was assessed. PCR was used to determine the expression levels of NLRP3, caspase-1, IL-1 $\beta$ and IL- $1 \alpha$ in the cell lysates. Furthermore, NLRP3 and apoptosis-associated speck-like protein (ASC) were detected via immunofluorescence assays and fluorescence microscopy was employed to determine the reactive oxygen species (ROS) levels in the THP-1 cells. The results indicated reduced levels of IL-18 and IL-1 $\beta$ in the supernatant of the cells of the pulegone groups when compared with those in the LPS + ATP/nigericin group. In addition, reduced mRNA production of inflammasome-associated genes was detected in the cell lysates after pulegone treatment. The immunofluorescence analyses indicated significantly reduced
\end{abstract}

Correspondence to: Dr Rong Liu or Professor Nan Zeng, Department of Pharmacology, College of Pharmacy, Chengdu University of TCM, 1166 Liutai Avenue, Wenjiang, Chengdu, Sichuan 611137, P.R. China

E-mail: liurong-1116@126.com

E-mail: zengnan666@126.com

${ }^{*}$ Contributed equally

Key words: pulegone, THP-1 cells, lipopolysaccharide + ATP/nigericin, NLR family pyrin domain containing 3 protein expression levels of NLRP3 and ASC in the pulegone groups, as well as co-localization of the NLRP3 and ASC proteins. The pulegone groups also exhibited significantly reduced ROS levels. Furthermore, a high concentration of potassium ions significantly reduced the secretion of IL-1 $\beta$ after induction/stimulation. In conclusion, the present study suggested that pulegone exerts its anti-inflammatory effects on LPS + ATP/nigericin-induced THP-1 cells via inhibition of NLRP3 expression, and its regulatory mechanism is associated with potassium channel and ROS pathways. It was hypothesized that pulegone first inhibits ROS signaling, to then inhibit NLRP3 expression as a downstream event. It appeared that NLRP3 may be situated further downstream and represented the link between inflammation and immunity.

\section{Introduction}

Inflammation is closely related to inflammatory factors such as inflammatory cytokines, which are released by the body to initiate/stimulate the inflammatory response and characterized by local redness, swelling, heat and pain, and may be accompanied by fever, leucocyte overproduction, macrophage activation, degeneration of parenchymal organs, necrosis and functional disorders of the heart, as well as even resulting in death (1). At present, chronic inflammatory processes are considered to be at the core of the pathologies of seven of the top ten leading causes of disease-associated mortality in developed countries. Of note, extensive evidence supports the role of inflammation in chronic pulmonary disease (2), heart disease (3), cancer (4), stroke (5), Alzheimer's disease (6), diabetes (7) and nephritis (8). Therefore, elucidation of the role of inflammation in the pathogenesis of various diseases has become one of the most urgent clinical problems to be addressed (9-12).

Pulegone is a derivative of monoterpene ketones occurring in the leaves and flowering tops of several members of the mint family. It is a constituent of peppermint essential oil, which has a wide range of applications in the food, fragrance and pharmaceutical industries (13). Furthermore, it is known to possess anti-bacterial, anti-oxidant and anti-inflammatory properties.

A previous study has indicated that pulegone has potent anti-inflammatory effects to reduce the lung index in rats with acute lung injury and alleviate inflammation-induced 
tissue swelling, and that the mechanisms include reduced transcription and expression of the inflammatory factor NLR family pyrin domain containing 3 (NLRP3) (14). However, the mechanisms underlying its anti-inflammatory effects have remained to be fully elucidated.

The NLPR3 inflammasome may be activated by a variety of endogenous or exogenous signals, which mainly include the following: i) Pathogens and their secreted toxins (15) ii) crystal compounds (16,17), iii) endogenous damage signals (18). Based on the above activating factors of the NLRP3 inflammasome, ATP, the cytotoxin nigericin or certain crystalloid substances, including calcium dihydrate pyrophosphate (CPPD) and alum, are frequently employed to stimulate the activation of the NLRP3 inflammasome in vitro.

The present study focused on the NLRP3 inflammasome pathway as part of the mechanism of action or pulegone. An in vitro THP-1 cell model of inflammation was established using ATP and the cellular toxin nigericin to explore the anti-inflammatory effects of pulegone, as well as the underlying mechanisms. In general, the results indicated that treatment with pulegone resulted in reduced secretion of interleukin (IL)-1 $\beta$ and IL-18, decreased expression and co-localization of NLRP3 and apoptosis-associated speck-like protein (ASC), decreased reactive oxygen species (ROS) generation and inhibition of potassium channels, which led to downstream suppression of the NLRP3 inflammasome.

\section{Materials and methods}

Cell line and culture. THP-1 cells (cat. no. 347258) were purchased from the cell bank of the Institute of Biochemistry and Cell Biology; Shanghai Institutes for Life Science; the Chinese Academy of Sciences. The cells were cultured in RPMI1640 medium (Gibco; Thermo Fisher Scientific, Inc.; cat. no. 1683014) containing $10 \%$ fetal bovine serum (Gibco; Thermo Fisher Scientific, Inc.; cat. no. 1715752) at $37^{\circ} \mathrm{C}$ and $5 \% \mathrm{CO}_{2}$ with saturated humidity.

Induced differentiation of THP-1 cells. THP-1 cells in the logarithmic growth phase were inoculated into 96-well plates $\left(2 \times 10^{5}\right.$ cells per well) and incubated with different concentrations of phorbol myristate acetate (PMA; $5,10,20,50$ and $100 \mathrm{ng} / \mathrm{ml}$ ) for $48 \mathrm{~h}$. The morphological changes and adherence of the THP-1 cells were then observed under a light microscope (AE2000; Motic).

In the subsequent experiments, the cells were stimulated with PMA ( $5 \mathrm{ng} / \mathrm{ml})$ for $48 \mathrm{~h}$ to induce them to differentiate into macrophages and adhere to the plates.

Activation conditions of the NLRP3 inflammasome. THP-1 cells in the logarithmic growth phase were inoculated into 96-well plates $\left(2 \times 10^{4}\right.$ cells per well) and incubated with PMA $(5 \mathrm{ng} / \mathrm{ml})$ for $48 \mathrm{~h}$. The cells were washed three times with PBS and then stimulated with lipopolysaccharide (LPS; $10 \mu \mathrm{g} / \mathrm{ml}$ ) for $3 \mathrm{~h}$, while the Normal group was not stimulated with LPS. The cells were washed twice with PBS and then activated using various stimulants at different concentrations. The concentrations of the stimulants and the stimulation times were as follows: ATP $(5 \mathrm{mM})$ and nigericin $(5 \mu \mathrm{M})$ for $1 \mathrm{~h}$; CPPD $(40 \mu \mathrm{g} / \mathrm{ml})$ and $\mathrm{CaCl}_{2}(5 \mathrm{mM})$ for $6 \mathrm{~h}$. After activation, the supernatant was collected and the levels of IL-1 $\beta$ and IL-18 were assessed via ELISA.

Cytotoxic effect of pulegone estimated via the MTS method. THP-1 cells were seeded in 96-well plates $\left(2 \times 10^{4} /\right.$ well) and induced with PMA $(5 \mathrm{ng} / \mathrm{ml})$ for $48 \mathrm{~h}$. After washing three times with PBS, the THP-1 cells were treated with different concentrations of pulegone or DMSO (six replicates for each experimental condition). The cells were then cultured for $24 \mathrm{~h}$. Subsequently, $20 \mu \mathrm{l}$ MTS was added to each well, followed by culture for an additional $3 \mathrm{~h}$. Finally, the optical density at $490 \mathrm{~nm}$ was assessed using a microplate reader (Thermo Fisher Scientific, Inc.).

Experimental grouping and treatments. The experiment included the Normal, LPS, LPS + ATP/nigericin, LPS + $\mathrm{ATP} /$ nigericin $+0.2 \%$ DMSO (solvent used to dissolve pulegone) and pulegone $(0.2,0.1$ and $0.05 \mathrm{mg} / \mathrm{ml})$ groups. The treatments were performed as follows: THP-1 cells were inoculated and induced as described in the previous section. All of the groups were then treated with LPS $(10 \mu \mathrm{g} / \mathrm{ml})$ for $3 \mathrm{~h}$, except for the Normal group. After washing twice with PBS, the cells were cultured in RPMI 1640 medium (Gibco; Thermo Fisher Scientific, Inc.; cat. no. 11875) containing different concentrations of pulegone for $1 \mathrm{~h}$ and then activated with different stimulants, with the concentrations of the stimulants and the stimulation times as mentioned above. Finally, the supernatants or lysates of the cells were collected and used for detection of the various factors.

ELISA. ELISA was used to detect IL-1 $\beta$ and IL-18 in the supernatants. The ELISA kits for cytokine profiling, including those for IL-1 $\beta$ and IL-18, were obtained from Boster Biological Technology. The THP-1 supernatants were harvested for ELISA according to the manufacturer's protocol.

PCR analysis. PCR was used to detect NLRP3, caspase-1, IL-1 $\beta$ and IL-1 $\alpha$ in the cell lysates. Total RNA was extracted from cells using TRIzol ${ }^{\circledR}$ reagent (Thermo Fisher Scientific, Inc.) and the RNA quality and concentration were measured using a Nanodrop 1000 Spectrophotometer (Thermo Fisher Scientific, Inc.). Approximately $1 \mu \mathrm{g}$ of total RNA was reverse-transcribed into complementary DNA using a FastQuant cDNA Kit (Tiangen Biotech Co. Ltd.) following the manufacturer's protocol. Quantitative PCR $\left(95^{\circ} \mathrm{C}\right.$ for $15 \mathrm{~min}$ followed by 39 cycles of $95^{\circ} \mathrm{C}$ for $10 \mathrm{sec}$ and $63.8^{\circ} \mathrm{C}$ for $30 \mathrm{sec}$, with a final extension step of $65^{\circ} \mathrm{C}$ for $5 \mathrm{sec}$.) was performed using a CFX96TM Real-Time PCR Detection System (Bio-Rad Laboratories, Inc.). The change in gene expression was calculated by $2^{-\Delta \Delta C}(19)$. The primer sequences used were as follows: NLRP3 forward, 5'-TGGCTGTAACATTCG GAGATTG-3' and reverse, 5'-GAAGTCACCGAGGGCGTT GT-3'; caspase-1 forward, 5'-GGAAACAAAAGTCGGCAG AG-3' and reverse, 5'-ACGCTGTACCCCAGATTTTG-3'; IL-1 $\beta$ forward, 5'-GGCCCTAAACAGATGAAGTGCT-3' and reverse, 5'-TGCCGCCATCCAGAGG-3'; IL-1 $\alpha$ forward, 5'-CAGTGAAATTTGACATGGGTG-3' and reverse, 5'-CAG GCATCTCCTTCAGCAG-3'; GADPH forward, 5'-CCACAT CGCTCAGACACCAT-3' and reverse, 5'-GGCAACAATATC CACTTTACCAGAGT-3'. 

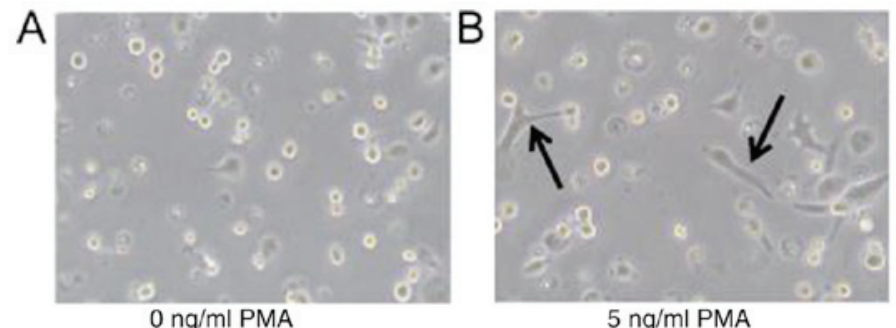

$5 \mathrm{ng} / \mathrm{ml} \mathrm{PMA}$

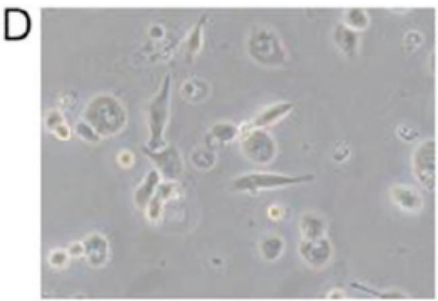

$20 \mathrm{ng} / \mathrm{ml}$ PMA

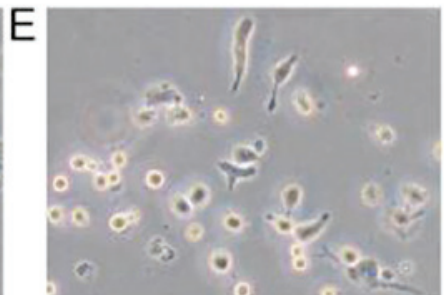

$50 \mathrm{ng} / \mathrm{ml}$ PMA

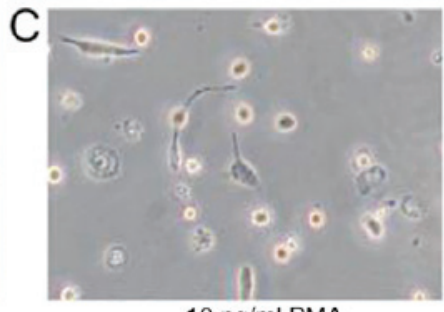

$10 \mathrm{ng} / \mathrm{ml}$ PMA

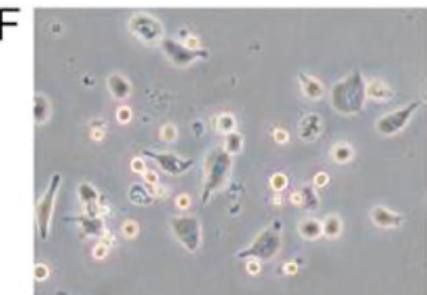

$10 \mathrm{ng} / \mathrm{ml} \mathrm{PMA}$

Figure 1. Morphological changes and adherence rates of THP-1 cells induced with different concentrations of PMA. Adherence rates of THP-1 cells induced with PMA at (A) 0, (B) 5, (C) 10, (D) 20, (E) 50 and (F) $100 \mathrm{ng} / \mathrm{ml}$. THP-1 cells were differentiated into typical macrophages subsequent to PMA treatment (black arrow; magnification, $\mathrm{x} 200)$. PMA, phorbol myristate acetate.

Immunofluorescence. THP-1 cells were stimulated to differentiate into macrophages induced with PMA on coverslips at a density of $5 \times 10^{5}$. After $48 \mathrm{~h}$, the cells were stimulated with LPS for $3 \mathrm{~h}$, followed by treatment with ATP $(5 \mathrm{mM})$ and nigericin $(5 \mu \mathrm{M})$ for $1 \mathrm{~h}$. Samples were washed twice with PBS and then fixed in $4 \%$ paraformaldehyde at room temperature for $30 \mathrm{~min}$. This was followed by washing three times with PBS and subsequent treatment with $0.2 \%$ Triton X-100 for $15 \mathrm{~min}$. The cells were then blocked with blocking buffer (5\% bovine serum albumin; Gibco; Thermo Fisher Scientific, Inc. cat. no. 1715752) for $1 \mathrm{~h}$ and incubated overnight with primary antibodies against NLRP3 (dilution ratio 1:100; AdipoGen; cat. no. AG-20B-0014) and ASC (dilution ratio 1:100; Novus Biologicals Ltd.; cat. no. NBP1-78978). This was added in error) at $4^{\circ} \mathrm{C}$, followed by incubation with FITC-tagged secondary antibody $\operatorname{IgG}(\mathrm{H}+\mathrm{L}$; dilution ratio 1:100 Proteintech Group, Inc.; cat. no. SA00003-1) and Alexa Fluor 594-tagged secondary antibody $\operatorname{IgG}(\mathrm{H}+\mathrm{L}$; dilution ratio 1:100; Proteintech Group, Inc.; cat. no. SA00006-4) for $1 \mathrm{~h}$ at room temperature. After washing with PBS, the cells were mounted and images were captured using a BA200 digital microscopic imaging system (Motic Electric Group Co., Ltd.). The Image-Pro Plus 6.0 image analysis software (Media Cybernetics, Inc.) was used to measure the integrated optical density of all images collected and the average optical density of each image was determined.

ROS. THP-1 cells were seeded in 48 -well plates $\left(5 \times 10^{5} /\right.$ well) and stimulated with $5 \mathrm{ng} / \mathrm{ml}$ PMA and $10 \mu \mathrm{g} / \mathrm{ml} \mathrm{LPS}$, and then treated with pulegone $(0.2$ or $0.1 \mathrm{mg} / \mathrm{ml})$ for $1 \mathrm{~h}$. ATP or nigericin was then added for $1 \mathrm{~h}$. After this stimulation, a 2',7'-dichlorodihydrofluorescein diacetate $\operatorname{ROS}$ probe $(0.5 \mu \mathrm{M})$ was added to the cells, followed by incubation for $30 \mathrm{~min}$ at $37^{\circ} \mathrm{C}$ in the dark. A fluorescence microscope (DMI3000; Leica) was employed to observe the cells after incubation.

Detection of potassium ions in the supernatant. THP-1 cells were seeded in 24 -well plates (5x105/well) and stimulated with $5 \mathrm{ng} / \mathrm{ml}$ PMA and $10 \mu \mathrm{g} / \mathrm{ml}$ LPS, followed by treatment with pulegone $(0.2 \mathrm{mg} / \mathrm{ml})$ for $1 \mathrm{~h}$. ATP or nigericin was then added for $1 \mathrm{~h}$. Subsequently, the THP-1 cells were incubated with $\mathrm{KCl}(100 \mathrm{mM})$ or RPMI 1640 medium only, without serum. The IL-1 $\beta$ levels in the supernatant were assayed via ELISA at $1 \mathrm{~h}$ post-incubation.

Statistical analysis. Values are expressed as the mean \pm standard error of the mean. Statistical analysis was performed using SPSS 20.0 software (IBM Corp.). Comparisons between groups were performed using ANOVAs with Fisher's protected least significant difference (LSD) tests used to determine the significance between groups. $\mathrm{P}<0.05$ was considered to indicate a statistically significant difference.

\section{Results}

Induced differentiation of THP-1 cells. Following incubation with different concentrations of PMA, the THP-1 cells became attached to the dish, while they did not adhere in the absence of PMA treatment. However, there was no significant difference in the level of adherence between the groups treated with different concentrations of PMA (Fig. 1).

Activation of the NLRP3 inflammasome. The results indicated that the IL-1 $\beta$ and IL-18 content in the supernatants of the cells was significantly increased in the LPS + ATP/nigericin group and the LPS + CPPD/CaCl 2 group $(\mathrm{P}<0.01)$. However, the LPS + ATP/nigericin treatment had a greater impact on IL-1 $\beta$ and IL-18 levels. Therefore, LPS + ATP/nigericin was selected for establishing the in vitro model for use in the subsequent experiments (Fig. 2A and B).

Cytotoxic effect of pulegone on THP-1 cells. The in vitro cytotoxicity experiments indicated that the vehicle DMSO (0.01-0.2\%) was not toxic to THP-1 cells (Fig. 2C). Furthermore, pulegone $(0-0.2 \mathrm{mg} / \mathrm{ml})$ had no toxic effect on THP-1 cells (Fig. 2D). Therefore, pulegone was used at concentrations of $\leq 0.2 \mathrm{mg} / \mathrm{ml}$ in all subsequent experiments. 

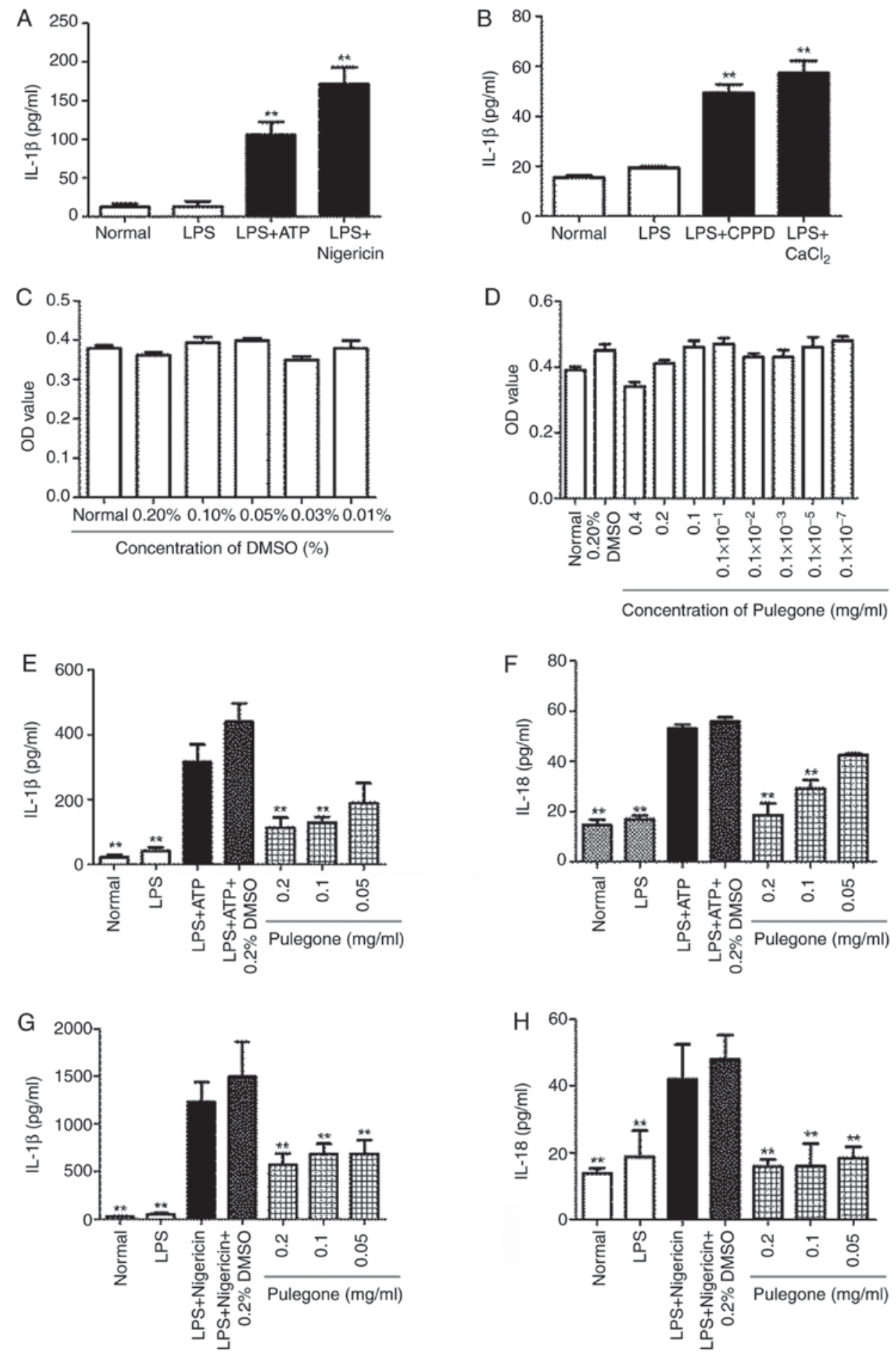

Figure 2. (A) Effects of LPS + ATP and LPS + nigericin targeting the NLR family pyrin domain containing 3 inflammasome on IL-1 $\beta$ release by THP-1 cells. (B) Effects of LPS + CPPD and LPS $+\mathrm{CaCl}_{2}$ targeting the NLR family pyrin domain containing 3 inflammasome on IL-1 $\beta$ release by THP-1 cells (C) Cytotoxic effects of DMSO on THP-1 cells as calculated using MTS cell viability assays. (D) Cytotoxic effects of pulegone on THP-1 cells as estimated via MTS cell viability assays. (E) Effects of pulegone on the levels of IL-1 $\beta$ in THP-1 cells induced by LPS + ATP. (F) Effects of pulegone on the levels of IL-18 in THP-1 cells induced by LPS + ATP. (G) Effects of pulegone on the levels of IL-1 $\beta$ in THP-1 cells induced by LPS + nigericin. (H) Effects of pulegone on the levels of IL-18 in THP-1 cells induced by LPS + nigericin. Values are expressed as the mean \pm standard error of the mean of $4-6$ samples per group. ${ }^{* *} \mathrm{P}<0.01$ compared with the model group. OD, optical density; LPS, lipopolysaccharide; IL, interleukin; CPPD, calcium dihydrate pyrophosphate.

Effect of pulegone on IL-1 $\beta$ and IL-18 secretion. As compared with those in the Normal group, the contents of IL- $1 \beta$ and IL-18 were significantly increased in the LPS + ATP and LPS + nigericin groups $(\mathrm{P}<0.05)$. The pulegone groups $(0.2$ and $0.1 \mathrm{mg} / \mathrm{ml}$ ) demonstrated significantly reduced hypersecretion of IL-1 $\beta$ and IL-18 $(\mathrm{P}<0.05)$ compared with that in the model group. Furthermore, there was a dose-dependent effect between the amount of pulegone used and the levels of the inflammatory cytokines, and these inhibitory effects of pulegone were most prominent at $0.2 \mathrm{mg} / \mathrm{ml}$. Furthermore, addition of DMSO $(0.2 \%)$ was indicated to have no significant influence on the hypersecretion of IL-1 $\beta$ and IL-18 (Fig. 2E-H). 

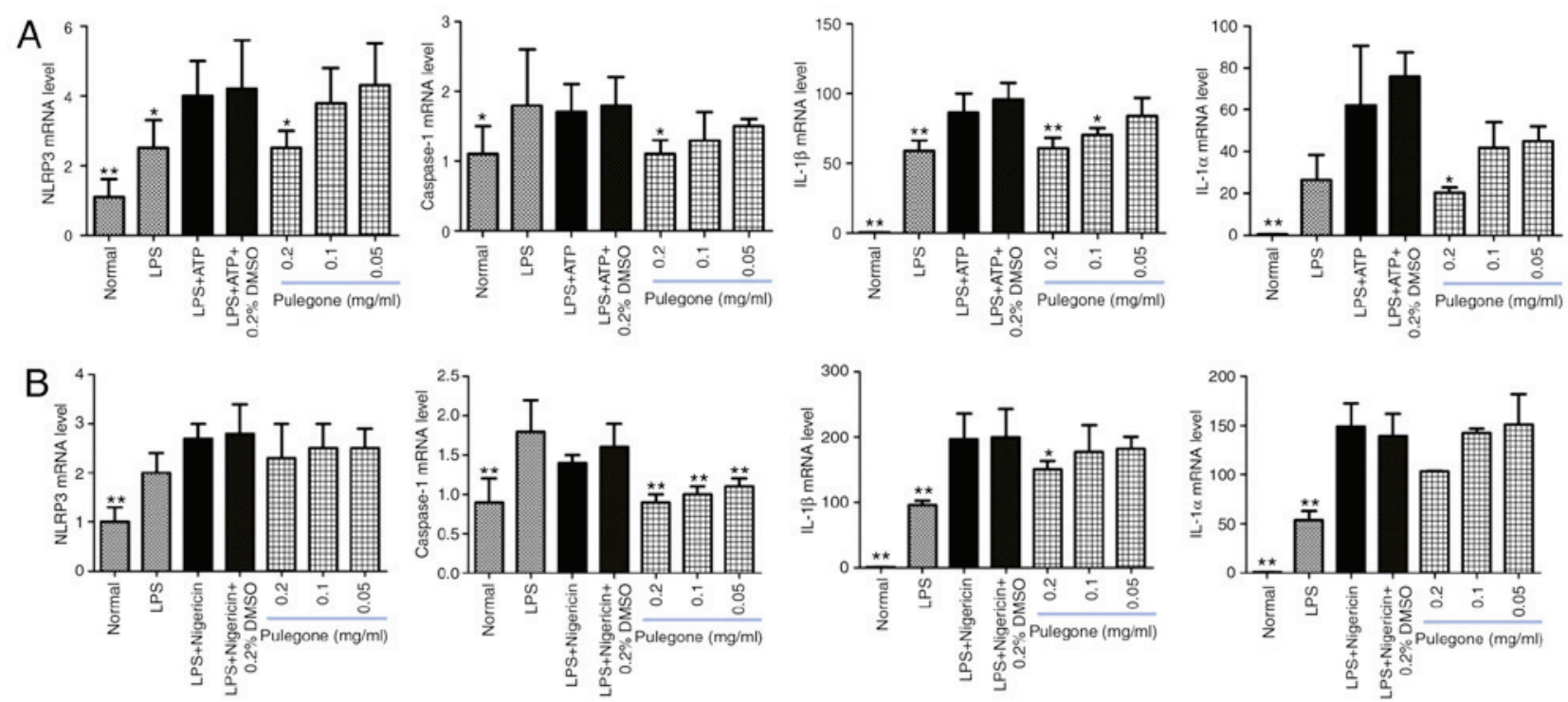

Figure 3. (A) Changes in the mRNA levels of NLRP3, caspase-1, IL-1 $\beta$ and IL-1 $\alpha$ after challenge with LPS and ATP. (B) The changes in the mRNA levels of NLRP3, Caspase-1, IL-1 $\beta$ and IL-1 $\alpha$ after challenge with LPS and nigericin. Values are expressed as the mean \pm standard error of the mean of 4-6 samples per group. " $\mathrm{P}<0.05,{ }^{* *} \mathrm{P}<0.01$ compared with the model group. NLRP3, NLR family pyrin domain containing 3; LPS, lipopolysaccharide; IL, interleukin.

A
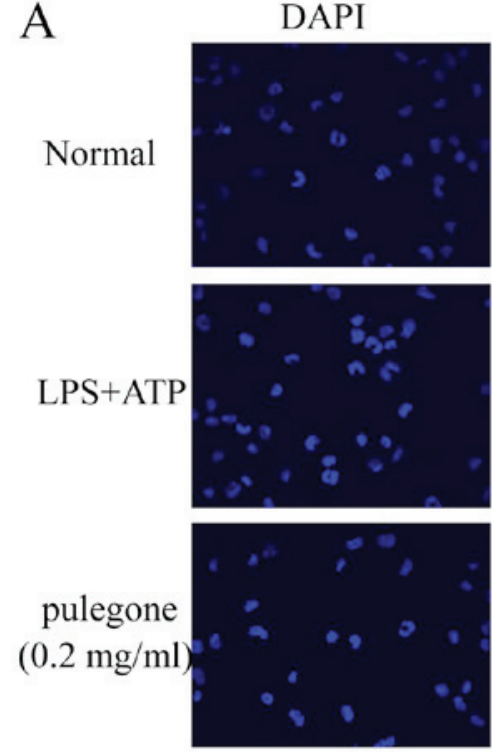

pulegone

$(0.1 \mathrm{mg} / \mathrm{ml}$

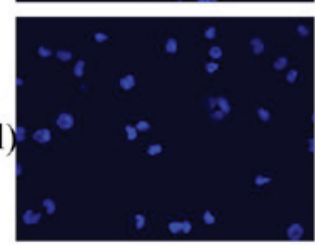

B

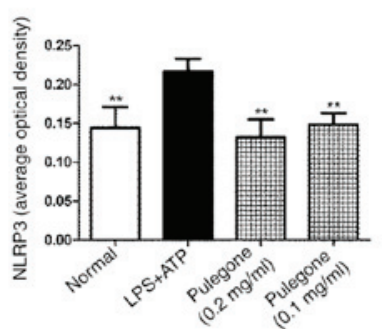

NLRP3
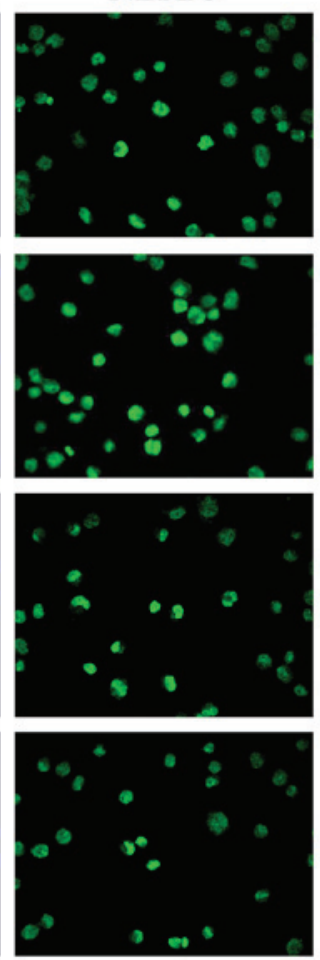

ASC
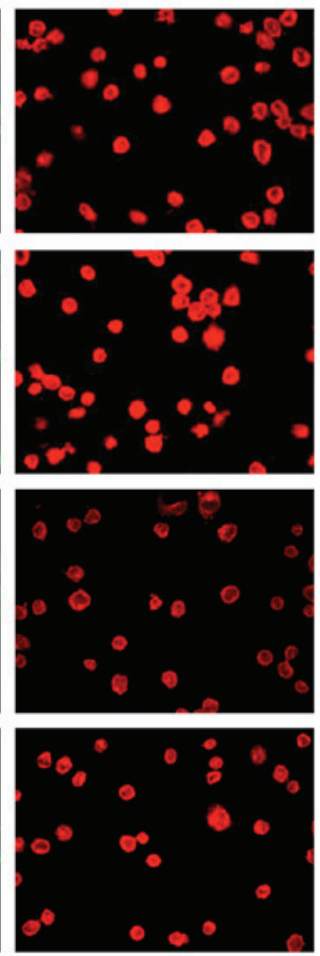

Merge
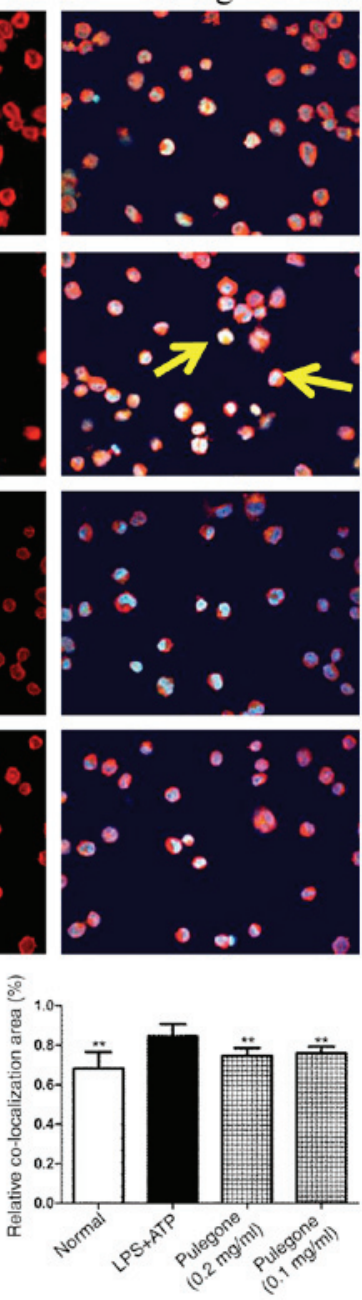

Figure 4. Protein levels of NLRP3 and ASC and co-localization of NLRP3 and ASC after challenge with LPS + ATP, as detected by immunofluorescence. (A) The protein levels of NLRP3 and ASC and the co-localization of the NLRP3 and ASC proteins after challenging with LPS + ATP (x40 magnification), the arrows show co-localization of the NLRP3 and ASC proteins. (B) The average optical density of NLRP3 and ASC and the co-localization of the NLRP3 and ASC proteins in the images was quantitatively determined. Values are expressed as the mean \pm standard error of the mean of $4-6$ samples per group. ${ }^{* *} \mathrm{P}<0.01$ compared with the model group. ASC, apoptosis-associated speck-like protein; NLRP3, NLR family pyrin domain containing 3; LPS, lipopolysaccharide. 
A
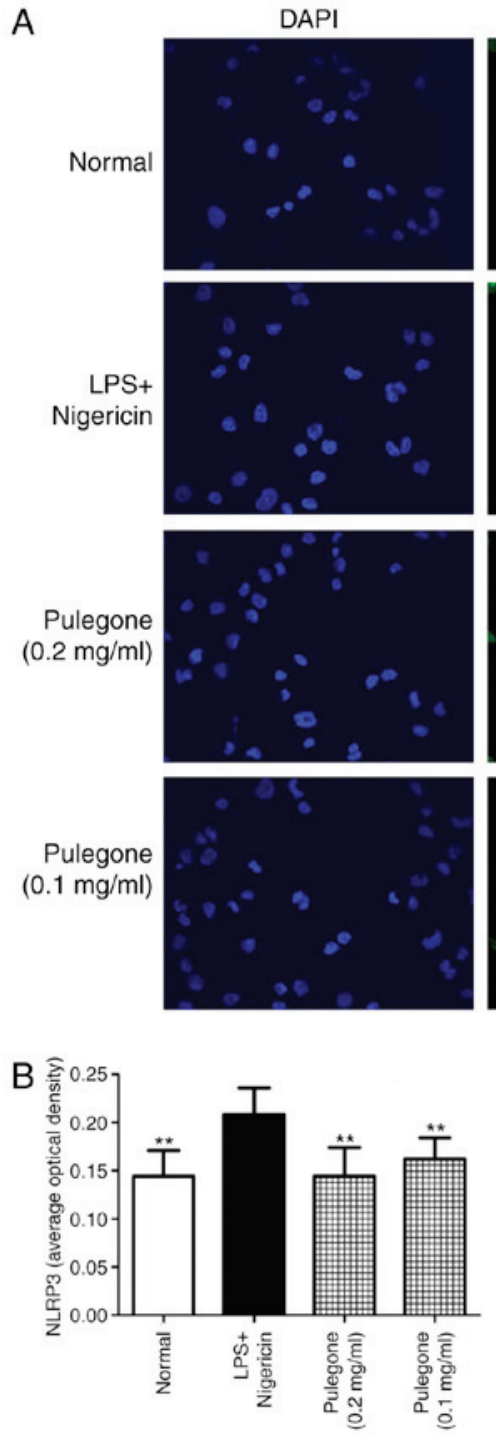
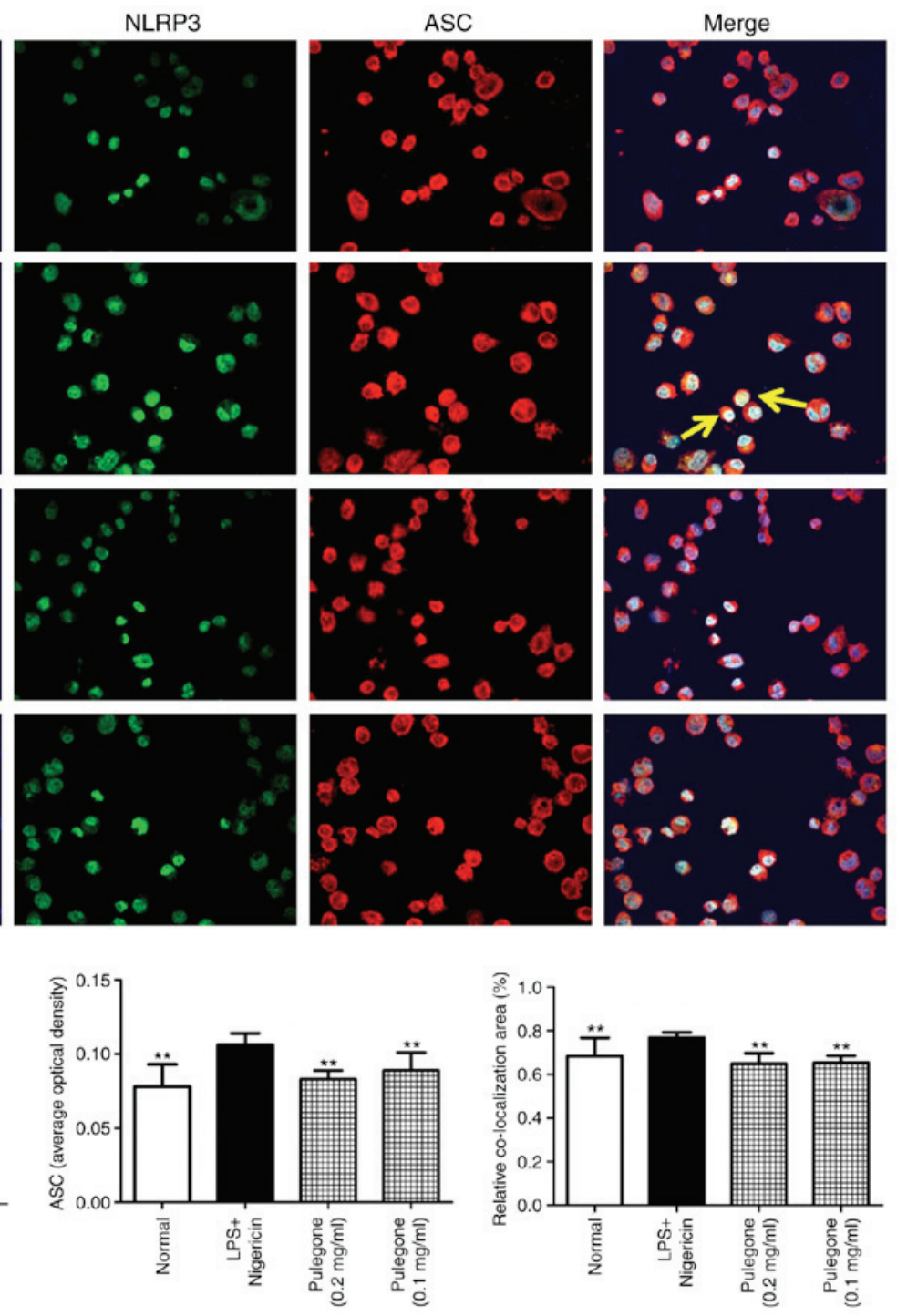

Figure 5. Protein levels of NLRP3 and ASC and co-localization of NLRP3 and ASC after challenge with LPS + nigericin, as detected by immunofluorescence. (A) Protein levels of NLRP3 and ASC and the co-localization of the NLRP3 and ASC proteins after challenge with LPS + nigericin (x40 magnification), the arrows show co-localization of the NLRP3 and ASC proteins. (B) The average optical density of NLRP3 and ASC and the co-localization of the NLRP3 and ASC proteins in the images was quantitatively determined. Values are expressed as the mean \pm standard error of the mean of $4-6$ samples per group. ${ }^{* *} \mathrm{P}<0.01$ compared with the model group. ASC, apoptosis-associated speck-like protein; NLRP3, NLR family pyrin domain containing 3; LPS, lipopolysaccharide.

Inhibitory effect of pulegone on mRNA levels in THP-I cells. Following the addition of pulegone, the mRNA levels of NLRP3, caspase-1, IL-1 $\beta$ and IL- $1 \alpha$ in the LPS + ATP (Fig. 3A) and LPS + nigericin groups (Fig. 3B) exhibited a decreasing trend. The inhibitory effects of pulegone were most prominent at $0.2 \mathrm{mg} / \mathrm{ml}$.

Co-localization of NLRP3 and ASC. After challenge with LPS + ATP or LPS + nigericin, the protein levels of NLRP3 and ASC in the model groups were significantly increased compared with those in the Normal group $(\mathrm{P}<0.01)$. Double immunofluorescent labeling revealed co-localization of the NLRP3 and ASC proteins in these THP-1 cells. Following treatment with pulegone $(0.2$ or $0.1 \mathrm{mg} / \mathrm{ml})$, the protein expression of NLRP3 and ASC was significantly inhibited $(\mathrm{P}<0.01)$ and the co-localization of the NLRP3 and ASC proteins was also significantly reduced $(\mathrm{P}<0.01)$. The inhibitory effects of pulegone were most prominent at the concentration of $0.2 \mathrm{mg} / \mathrm{ml}$ (Figs. 4 and 5).
Reduction of ROS levels by pulegone. After challenge with LPS + ATP, the ROS levels in the THP-1 cells of the model group were significantly increased compared with those in the Normal group $(\mathrm{P}<0.01)$. Of note, the pulegone groups $(0.2$ and $0.1 \mathrm{mg} / \mathrm{ml})$ demonstrated significantly reduced ROS levels $(\mathrm{P}<0.01)$. The inhibitory effects of pulegone were most prominent at the concentration of $0.2 \mathrm{mg} / \mathrm{ml}$ (Fig. 6).

Effect of potassium ions on the secretion of IL-1 $\beta$. Compared with that in the Normal group, the IL-1 $\beta$ content in the supernatant was significantly increased in the LPS + ATP and LPS + nigericin groups in the absence of potassium ions $(\mathrm{P}<0.05)$. In the pulegone $(0.2 \mathrm{mg} / \mathrm{ml})$ group, the hypersecretion of IL-1 $\beta(\mathrm{P}<0.05)$ was significantly reduced compared with that in the model group. However, after pre-treatment with potassium ions, there was no significant difference among the four groups (Normal, LPS + ATP, LPS + nigericin and $0.2 \mathrm{mg} / \mathrm{ml}$ pulegone) (Fig. 7A). 


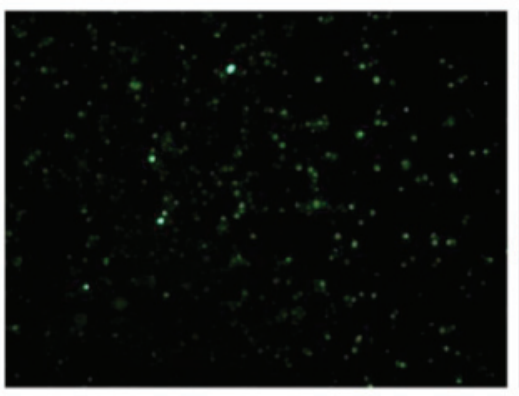

Normal

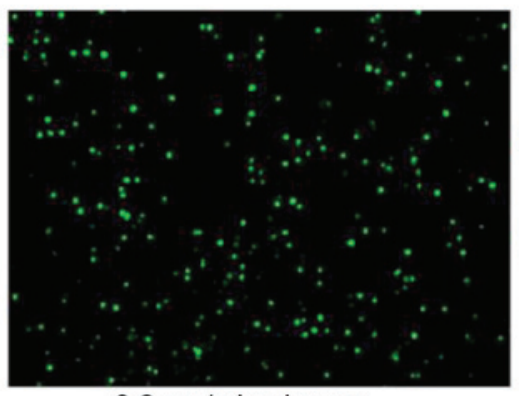

$0.2 \mathrm{mg} / \mathrm{ml}$ pulegone

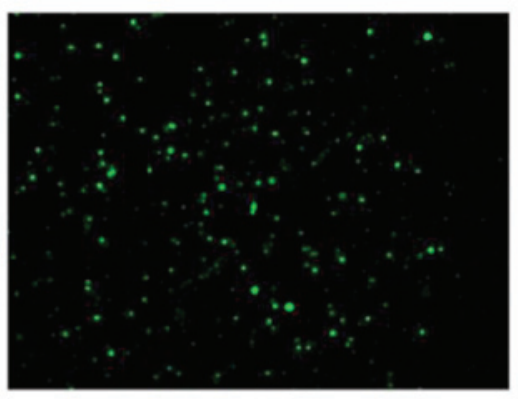

LPS

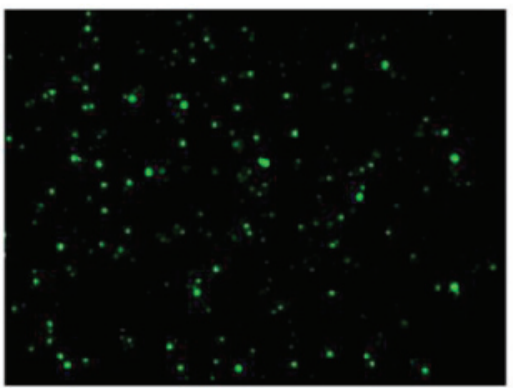

$0.1 \mathrm{mg} / \mathrm{ml}$ pulegone

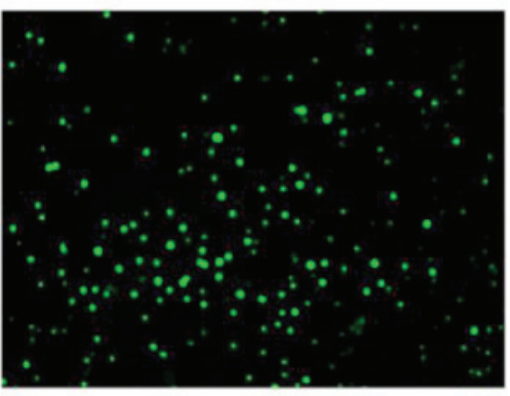

LPS+ATP

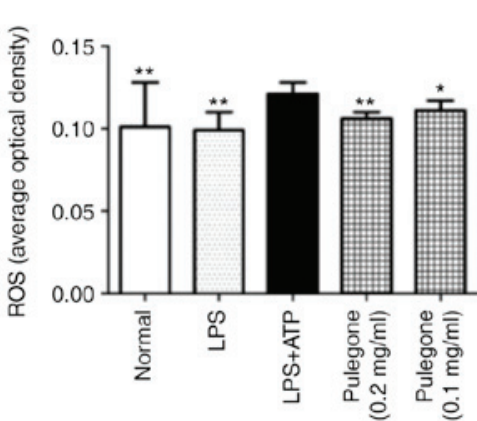

Figure 6. Effect of pulegone on the ROS levels in THP-1 cells induced by LPS + ATP (x10 magnification). Values are expressed as the mean \pm standard error of the mean of six samples per group. ${ }^{*} \mathrm{P}<0.05,{ }^{* * *} \mathrm{P}<0.01$ compared with the model group. ROS, reactive oxygen species; LPS, lipopolysaccharide.
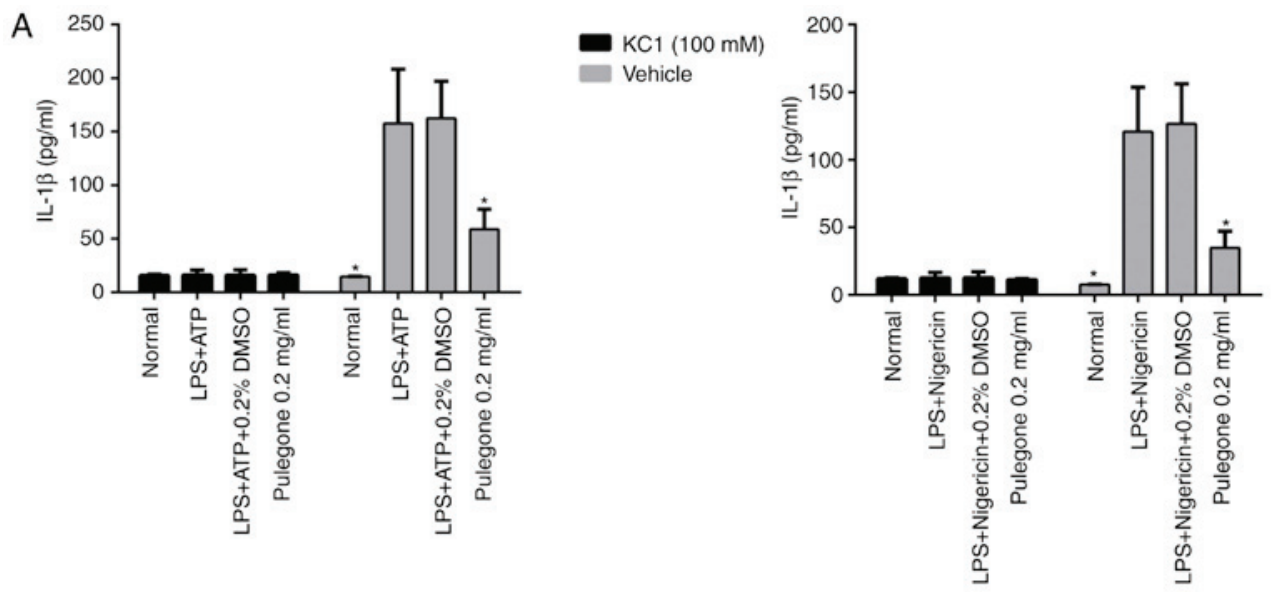

B

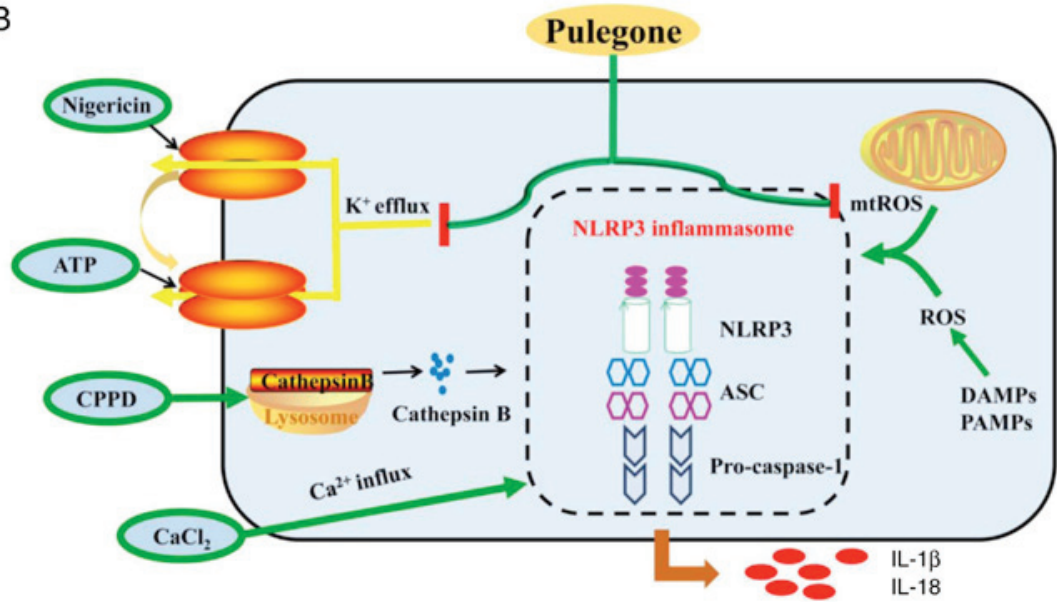

Figure 7. (A) Effect of potassium ions on the secretion of IL-1 $\beta$ in the supernatant. Values are expressed as the mean \pm standard error of the mean of four samples per group. ${ }^{*} \mathrm{P}<0.05$ compared with the model group. (B) Schematic depicting the NLRP3 inflammasome signaling pathway. IL, interleukin; LPS, lipopolysaccharide; CPPD, calcium dihydrate pyrophosphate; mtROS, mitochondrial reactive oxygen species; ASC, apoptosis-associated speck-like protein; NLRP3, NLR family pyrin domain containing 3; PAMP, pathogen-associated molecular pattern; DAMP, damage-associated molecular pattern. 


\section{Discussion}

It has been reported that pulegone possesses anti-inflammatory (20), anti-secretory, anti-pyretic (21), anti-oxidant (22), anti-cholinesterase $(23,24)$, free radical scavenging and lipoxygenase inhibitory effects (25). However, the anti-inflammatory effects of pulegone have only been reported to lead to the release of inflammatory mediators, while the mechanisms underlying its anti-inflammatory effects have remained to be fully elucidated. The aim of the present study was to assess the inflammatory mediators influenced by pulegone and to further investigate the mechanisms of action with regard to the NLRP3 inflammasome.

The inflammatory cytokines IL-1 $\beta$ and IL-18 are initially produced as inactive precursor proteins and require the generation of a signaling platform termed the inflammasome, which processes IL-1 $\beta$ and IL-18 into their mature bioactive forms prior to being released from the cells (26-28). Thus, the secretion of mature IL-1 $\beta$ requires two signals. Regarding the first, innate receptors (such as Toll-like receptor 4) are engaged by an LPS ligand from Gram-negative bacteria to activate $N F-\kappa B$ and induce transcription of the gene encoding the inactive pro-IL-1 $\beta$ precursor (29). In terms of the second signal, inflammasome activation is triggered via mediators, including ATP or nigericin. Therefore, LPS + ATP and LPS + nigericin were employed in the present study to generate the in vitro cell models.

Inflammasomes consist of an NLR protein, e.g. NLRP3, that recruits the adapter protein ASC and caspase-1 into an oligomeric complex, which leads to the auto-proteolytic processing of pro-caspase-1 to its active form that is able to cleave the pro-IL-1 $\beta$ and pro-IL-18 precursors into their mature secreted forms $(30,31)$. The activation of the inflammasome may also lead to a necrotic type of cell death termed pyroptosis (32). The NLRP3 inflammasome is able to recognize danger signals from pathogen-associated molecular patterns and damage-associated molecular patterns, and this recognition activates four different responses within the cells (33): i) Changes in potassium concentration, ii) induction of ROS production, iii) changes in calcium ion concentration and iv) induction of lysosomal damage. Pulegone treatment is able to suppress these effects of the NLRP3 inflammasome with regard to potassium channel activity and generation of ROS, which may serve to induce the pro-inflammatory cytokine-mediated immune responses, as illustrated in Fig. 7B.

Subsequent to NLRP3 activation, the recruitment of the ASC adapter protein, cleavage of pro-caspase-1 into activated caspase-1, and the maturation and secretion of IL-1 $\beta$ and IL-18 occur, inducing pyroptosis and inflammatory tissue injury (33).

The efflux of potassium ions from the THP-1 cells was reported to be mediated by stimulation of purinoceptor 7 by the activator ATP, but the mechanism of activation via nigericin occurs via the formation of a transmembrane pore in the plasma membrane (34-38). The results of the present study indicated that the hypersecretion of IL-1 $\beta$ and IL-18 into the supernatant of THP-1 macrophages induced by ATP and nigericin was significantly inhibited by treatment with 0.2 or $0.1 \mathrm{mg} / \mathrm{ml}$ pulegone, with the inhibitory effects of pulegone being most prominent at the concentration of $0.2 \mathrm{mg} / \mathrm{ml}$. Pulegone at 0.2 or $0.1 \mathrm{mg} / \mathrm{ml}$ also significantly reduced the mRNA expression of NLRP3, caspase-1, IL-1 $\beta$ and IL- $1 \alpha$, and the expression of the NLRP3 and ASC proteins was also significantly downregulated, as assessed by immunofluorescence methods, suggesting that pulegone had a potent anti-inflammatory effect in vitro and that its mechanism of action involved suppression of the activation of the NLRP3 inflammasome.

In addition, the anti-inflammatory properties of pulegone in THP-1 macrophages induced by CPPD and $\mathrm{CaCl}_{2}$ were investigated in the present study. The endocytosis of CPPD crystals may cause lysosomal damage or rupture, leading to release of cathepsin into the cytosol, which is able to induce the activation of the NLRP3 inflammasome. By contrast, $\mathrm{CaCl}_{2}$ activates the NLRP3 inflammasome by increasing the intracellular concentration of calcium ions. The results of preliminary experiments (39) revealed that 0.2 and $0.1 \mathrm{mg} / \mathrm{ml}$ pulegone had a significant inhibitory effect on the secretion of IL-1 $\beta$ by THP-1 macrophages induced by CPPD or $\mathrm{CaCl}_{2}$, suggesting that the anti-inflammatory effect of pulegone may affect the function of calcium ion channels and induce lysosomal damage; however, the underlying mechanisms remained to be determined.

The results of the present study suggested that pulegone significantly inhibited the hypersecretion of IL-1 $\beta$ and IL-18, as well as the high expression of NLRP3, pro-caspase-1 and pro-IL-1, and the generation of ROS in THP-1 macrophages induced by ATP and nigericin. In addition, potassium ions were indicated to affect the secretion of IL-1 $\beta$, as high concentrations of potassium ions from the extracellular environment significantly reduced the hypersecretion of IL-1 $\beta$ induced by LPS + ATP/nigericin in THP-1 cells. As such, it is apparent that pulegone is able to suppress the NLRP3 inflammasome by means of inhibition of potassium channels and decreased ROS generation. It appears that auto-immune responses are situated downstream of NLRP3, which may therefore act as a link between inflammation and immunity. However, only the downstream products/targets of the NLRP3 pathway were investigated in the present study and whether pulegone also inhibits upstream stimulatory factors of the NLRP3 pathway remains to be investigated.

\section{Acknowledgements}

Not applicable.

\section{Funding}

The present study was supported by National Nature Science Foundation of China (grant nos. 81473399, J1310034-09); Department Pharmacology, Sichuan Provincial Science and Technology, Sichuan Province Youth Science and Technology Innovation Team (grant no. 2014TD0007).

\section{Availability of data and materials}

The datasets used and/or analyzed during the present study are available from the corresponding author on reasonable request.

\section{Authors' contributions}

QY designed and performed experiments, analyzed data and wrote the paper; QL, HL, FW, RL performed experiments 
and analyzed data; NZ designed experiments and analyzed data; RL designed experiments, analyzed data, and provided editorial input. All authors approved the final manuscript.

\section{Ethics approval and consent to participate}

Not applicable.

\section{Patient consent for publication}

Not applicable.

\section{Competing interests}

The authors declare that they have no competing interests.

\section{References}

1. He L, Wang T, Chen BW, Lu FM and Xu J: Puerarin inhibits apoptosis and inflammation in myocardial cells via PPARo expression in rats with chronic heart failure. Exp Ther Med 18: 3347-3356, 2019

2. Gan WQ, Man SF, Senthilselvan A and Sin DD: Association between chronic obstructive pulmonary disease and systemic inflammation: A systematic review and a meta-analysis Thorax 59: 574-580, 2004.

3. Awan $\mathrm{Z}$ and Genest J: Inflammation modulation and cardiovascular disease prevention. Eur J Prev Cardiol 22: 719-733, 2015.

4. Hanahan D and Weinberg RA: Hallmarks of cancer: The next generation. Cell 144: 646-674, 2011

5. Kawabori $\mathrm{M}$ and Yenari MA: Inflammatory responses in brain ischemia. Curr Med Chem 22: 1258-1277, 2015.

6. Amor S, Puentes F, Baker D and van der Valk P: Inflammation in neurodegenerative diseases. Immunology 129: 154-169, 2010.

7. Biondi-Zoccai GG, Abbate A, Liuzzo G and Biasucci LM Atherothrombosis, inflammation, and diabetes. J Am Coll Cardiol 41: 1071-1077, 2003.

8. Zheng $\mathrm{Z}$ and Zheng F: Immune cells and inflammation in diabetic nephropathy. J Diabetes Res 2016: 1841690, 2016.

9. Clevers $\mathrm{H}$ : At the crossroads of inflammation and cancer. Cell 118: 671-674, 2004.

10. Gupta RA and Dubois RN: Colorectal cancer prevention and treatment by inhibition of cyclooxygenase-2. Nat Rev Cancer 1: 11-21, 2001.

11. Balkwill F and Coussens LM: Cancer: An inflammatory link Nature 431: 405-406, 2004

12. Pikarsky E, Porat RM, Stein I, Abramovitch R, Amit S, Kasem S, Gutkovich-Pyest E, Urieli-Shoval S, Galun E and Ben-Neriah Y: NF-kappaB functions as a tumour promoter in inflammation-associated cancer. Nature 431: 461-466, 2004.

13. Adlard ER: Handbook of Essential Oils. Science, Technology and Applications. Chromatographia 72: 1021, 2010.

14. Chen F, Wei G, Xu J, Ma H and Wang Q: Naringin ameliorates the high glucose-induced rat mesangial cell inflammatory reaction by modulating the NLRP3 Inflammasome. BMC Complementary Alternative Med 18: 192, 2018

15. Li ZJ, Choi DK, Sohn KC, Seo MS, Lee HE, Lee Y, Seo YJ, Lee YH, Shi G, Zouboulis CC, et al: Propionibacterium acnes activates the NLRP3 inflammasome in human sebocytes. J Invest Dermatol 134: 2747-2756, 2014

16. Zhou R, Yazdi AS, Menu P and Tschopp J: A role for mitochondria in NLRP3 inflammasome activation. Nature 469: 221-225, 2011.

17. Guarda G, Dostert C, Staehli F, Cabalzar K, Castillo R, Tardivel A, Schneider P and Tschopp J: T cells dampen innate immune responses through inhibition of NLRP1 and NLRP3 inflammasomes. Nature 460: 269-273, 2009.

18. Darisipudi MN, Thomasova D, Mulay SR, Brech D, Noessner E, Liapis $\mathrm{H}$ and Anders HJ: Uromodulin triggers IL-1 $\beta$-dependent innateimmunity via the NLRP3 inflammasome. J Am Soc Nephrol 23: 1783-1789, 2012
19. Xu F, Wen T, Wang F, Sang W and Zeng N: Protective effect of cinnamicaldehyde in endotoxin poisoning mice. Immunopharmacol Immunotoxicol 38: 455-463, 2016.

20. Kawata JK, Kameda M and Miyazawa M: Cyclooxygenase-2 inhibitory effects of monoterpenoids with a p-menthane skeleton. Int J Essent Oil Ther 2: 145-148, 2008.

21. Ortiz de Urbina AV, Martín ML, Montero MJ, Morán A and San Román L: Sedating and antipyretic activity of essential oil of Calamintha sylvatica subsp. Ascendens J Ethnopharmacol 25: $165-171,1989$.

22. Ruberto G and Baratta MT: Antioxidant activity of selected essential oil components in two lipid model systems. Food Chem 69: 167-174, 2000.

23. Ryan MF and Byrne O: Plant-insect coevolution and inhibition of acetylcholinesterase. J Chem Ecol 14: 1965-1975, 1988.

24. Miyazawa M, Watanabe $\mathrm{H}$ and Kameoka H: Inhibition of acetylcholinesterase activity by monoterpenoids with a p-menthane skeleton. J Agric Food Chem 45: 677-679, 1997.

25. Demirci B, Temel HE, Portakal T, Kırmızıbekmez H, Demirci F and Başer KHC: Inhibitory effect of Calamintha nepeta subsp. glandulosa essential oil on lipoxygenase. Turk J Biochem 36: 290-295, 2011.

26. Cerretti DP, Kozlosky CJ, Mosley B, Nelson N, Van Ness K, Greenstreet TA, March CJ, Kronheim SR, Druck T, Cannizzaro LA, et al: Molecular cloning of the interleukin-1 beta converting enzyme. Science 256: 97-100, 1992.

27. Thornberry NA, Bull HG, Calaycay JR, Chapman KT, Howard AD, Kostura MJ, Miller DK, Molineaux SM, Weidner JR, Aunins J, et al: A novel heterodimeric cysteine protease is required for interleukin-1 beta processing in monocytes. Nature 356: 768-774, 1992.

28. Ghayur T, Banerjee S, Hugunin M, Butler D, Herzog L, Carter A, Quintal L, Sekut L, Talanian R, Paskind M, et al: Caspase-1 processes IFN-gamma-inducing factor and regulates LPS-induced IFN-gamma production. Nature 386: 619-623, 1997.

29. Skeldon AM,Faraj M and Saleh M: Caspases and inflammasomes in metabolic inflammation. Immunol Cell Biol 92: 304-313, 2014

30. Tack CJ, Stienstra R, Joosten LA and Netea MG: Inflammation links excess fat to insulin resistance: The role of the interleukin-1 family. Immunol Rev 249: 239-252, 2012.

31. Martinon F, Burns K and Tschopp J: The inflammasome: A molecular platform triggering activation of inflammatory caspases and processing of proIL-beta. Mol Cell 10: 417-426, 2002.

32. Vanaja SK, Rathinam VA and Fitzgerald KA: Mechanisms of inflammasome activation: Recent advances and novel insights. Trends Cell Biol 25: 308-315, 2015.

33. Jo EK, Kim JK, Shin DM and Sasakawa C: Molecular mechanisms regulating NLRP3 inflammasome activation. Cell Mol Immunol 13: 148-159, 2016

34. He Y, Zeng MY, Yang D, Motro B and Núñez G: NEK7 is an essential mediator of NLRP3 activation downstream of potassium efflux. Nature 530: 354-357, 2016.

35. Rivers-Auty $\mathbf{J}$ and Brough D: Potassium efflux fires the canon: Potassium efflux as a common trigger for canonical and noncanonical NLRP3 pathways. Eur J Immunol 45: 2758-2761, 2015.

36. Rühl S and Broz P: Caspase-11 activates a canonical NLRP3 inflammasome by promoting $\mathrm{K}(+)$ efflux. Eur J Immunol 45: 2927-2936, 2015

37. Segovia J, Sabbah A, Mgbemena V, Tsai SY, Chang TH, Berton MT, Morris IR, Allen IC, Ting JP and Bose S: TLR2/MyD88/NF- $\kappa$ B pathway, reactive oxygen species, potassium efflux activates NLRP3/ASC inflammasome during respiratory syncytial virus infection. PLoS One 7: e29695, 2012.

38. Muñoz-Planillo R, Kuffa P, Martníez-Colón G, Smith BL, Rajendiran TM and Núñez G: $\mathrm{K}^{+}$efflux is the common trigger of NLRP3 inflammasome activation by bacterial toxins and particulate matter, Immunity 38: 1142-1153, 2013.

39. Wang F, Xu F, Wen T, et al: Effect of essential oil from Schizonepeta tenuifolia on the mechanism of NLRP3 inflammasome activation in THP-1 cells. J Chin Med Materials 40: 689-694, 2017 (In Chinese).

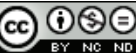

This work is licensed under a Creative Commons Attribution-NonCommercial-NoDerivatives 4.0 International (CC BY-NC-ND 4.0) License. 